\title{
THAT SAME INDEPENDENT NEW FASHION
}

\section{Y. Zhukova. That Same Independent New Fashion}

The fashion is always limited in time and the new evolutionary round of the fashion industry (FI) development will not be an exception. The independence of FI is a result of changing opportunities and needs of a person as a consumer. The person-consumer is dependence on the gadget. Nowadays, it directly affects the new technologies of the suit and clothes creation. New requirements have influenced the rapid development, the growing value of the Internet, the e-commerce and the new technologies of the clothes creation. They are the 3D, 4D printing, nanotechnologies (NT), smart clothes: the wearable electronics and smart clothing for healthcare, biofabrication (BF), etc. The emergence of the new technologies in the environmentally friendly clothes creation permitted to process the waste and the salvage into new materials. It gave the chance to globally reconsider the relations with the environment and the consumption without killing animals. It was found out that the latest development reflected the epoch, the time and the human needs of the Third Millennium. This research introduced the new term - Independent New Fashion (INF), in order to highlight the independent historical moment of the new round of FI evolutionary development. The further research is crucial in this field. The subject of the paper is the creation, the presentation and the development of the independent fashion and the new clothes. The chronological framework of the paper ranges from 1996 till the present time.

Keywords: Independent New Fashion (INF), biofabrication (BF), fashionable clothes presentation formats, science and design collaboration, modern design community, innovations.

\section{Я. О. Жукова. Незалежна Нова Мода}

Актуальність. Мода як одна 3 форм суспільної свідомості завжди залежна та обмежена в часі, тому новий еволюційний цикл розвитку індустрії моди (IM), у глобальному сенсі, не є винятком. Проте локально IM нині здобула незалежність, що засвідчує зміни потреб та можливостей споживача.

Мета. Означити незалежність як історичний момент нового етапу еволюційного розвитку IM.

Новизна. У міждисциплінарне наукове поле культурології та сучасної IM впроваджено новий термін - Незалежна Нова Мода (ННМ).

Методи. Методологічна основа - культурологічний метод. Також використано методи: культурно-історичний, порівняльний, комплексний та інформаційний.

Результати. Контекст ННМ відображає швидкий розвиток та зростаючу цінність Інтернету, електронної комерції та нових технологій створення одягу: 3D-, 4D-друку, нанотехнологій (HT), «розумного одягу» (носимих обчислювальних пристроїв та «розумного одягу» для сфери охорони здоров’я), біофабрикації, тощо. Це відображає зміну епохи, часу і потреб людини третього тисячоліття та сприяє появі новітнього одягу з розширеним функціоналом. Наукових праць на цю тему нині немає, однак тема потребує серйозних подальших досліджень.

Практичне значення. Порівняно з традиційними виробничими процесами новий технологічний потенціал має немало переваг: швидке проєктування; своєчасність і зниження витрат, пов'язаних зі зберіганням, складуванням, упаковкою та транспортуванням; можливість істотно переглянути сезонні цикли створення одягу; календар доставки; розробити шляхи нових естетичних ліній та інноваційних форматів презентації одягу.

Висновки. Розширена науково-дослідницька галузь культурології. Означений процес культурного розвитку модних форматів презентації одягу, досліджений у результаті виявлення особливостей творчості видатних діячів, котрі створюють світові культурні шедеври і розвивають нові культурні стилі, дозволяє припустити, що ННМ посідає позиції креативності, новизни в процесах культурної діяльності, які створюють матеріальні цінності - одяг, взуття, аксесуари, ювелірні вироби. Визначені положення, роль і хронологічна специфіка є підтвердженням переходів людства до нових стадій розвитку культури, суспільства i цивілізації. Дослідження досягло мети та засвідчило необхідність подальших розробок у зазначеному напрямі.

Ключові слова: Незалежна Нова Мода (НHМ), модні формати презентаиї нового одягу, біофабрикачія, колаборащія науки та дизайну, спільнота сучасного дизайну, інновачї.

Introduction. Fashion has changed for ages expressing time and human needs. Historically, in global relation the fashion is always depends on changes in culture, science, art, industry, religion, policy, philosophy, history, esthetics, sociology, etc.

\footnotetext{
* This work is licensed under a Creative Commons Attribution-NonCommercial-ShareAlike 4.0 International License.

${ }^{1}$ This research article is a part of our PhD dissertation, entitled "Theatricalization of fashion shows: semiotic aspect" (Kharkiv State Academy of Culture).
} 
(Kaiser, 2012), (Waddell, 2004). Rapid innovative changes continue to happen today, directly in the fashion industry (FI) in the local sense. It is one of the factors of its growing independence today. This research introduces the new term - Independent New Fashion (INF), in order to highlight the independence of the historical moment of the new round of the evolutionary development of FI. The factors, which gave FI independence, resulted from the changed opportunities and needs of a person as a consumer. Internet, e-commerce and new technologies of clothes creation are influenced new requirements of the rapid development and the growing value. Such a possibility of FI as independence of time effects and changes money, the principles, laws, creation of suits and clothes. It creates and approves new opportunities of the presentation, acquisition, use, utilization or recycling today.

Christian Dior made the seasonal schedule of work twice a year: spring-summer and fall-winter in the middle of the XX century (Gabet \& Müller, 2017). FI got a historical opportunity of independence in the point of creation and variations of a new commercial rhythm due to opportunities of the Internet and online of broadcasting 24/7. FI gained independence to sell the goods in any place of the world through online stores 24/7, thanks to e-commerce. Blogs, vlogs and social networks gave independence to designers and brands to present to themselves and their work through the Internet 24/7.

The history of the suit defines its functions: esthetic, utilitarian and designation of class differences. The suit and clothes began to get new functions which have never been earlier in the history having considerably expanded the functional value today. New clothes creation technologies of 3D (Cvetković, 2018), 4D printing, nanotechnologies (NNI), smart clothes: the wearable electronics and smart clothing for healthcare, biofabrication (BF), etc. promoted this (Crump, 1992). 3D modeling of a person's body doesn't allow to depend on of the size available, nonstandard figure. Emergence of new technologies of creation of environmentally friendly clothes, allows to process waste and salvage into new materials. What in its turn, gives the chance to a person, without killing animals, to globally reconsider the relations with the environment and consumption (Yang et al., 2017).

The dependence of a person on the gadget, is directly affects new technologies of creation suit and clothes now days (Huang \& Chang, 2018). They have to be not only convenient, comfortable, but also correspond to the pace of the changes happening in the world. It allows a person at time necessary for him to independently create clothes and a suit, saving time and forces for the exhausting choice and fitting. Technologies of clothes and suit creation adequately take the place of portable personal gadgets, equally with mobile phones or tablets. Their rapid development goes on the way of independence of sewing productions.

The fashion is always limited in time and the new evolutionary round of FI development will not be an exception. It is fast developing dynamics led to the introduction in this research, the new term Independent New Fashion (INF). It requires to the further research. The purpose of the scientific research is to establish a new term into the interdisciplinary field of cultural studies and FI INF of the clothes presentation format, footwear, accessories and jewelry. They have emerged as the result of the progress, after investigating the appearance, development and transformation of fashionable clothes presentation formats.

The purposes of the research: to define the place, the role and the peculiarities of the fashionable clothes presentation formats; to analyze the appearance of new types of clothes; to develop the research field of the semiotic and cultural studies; to confirm the necessity of the further research of the fashionable clothes presentation formats. The level of the theme development: the research papers dealing with a topic have not been published yet. The sources of the research paper included the scientific and popular articles and the latest practical, experimental and laboratory research material. The chronological framework of the paper ranges from 1996 till nowadays. The subject of the paper is the creation, presentation and development of the independent fashion and new clothes.

The fashion independence changed the format. The presentation format is the collection contents expressed in a new form. Fashionable clothes presentation formats are the fashion trends of the time. The fashionable clothes presentation format promotes transformation of new clothes into fashionable. There are contrasts between the presentations, ideas development, functional assignments, the image creations and sales. They do not only create the fashionable clothes presentation format. They also allow to look for the approach varieties. All these promote the personal identity expressing in order to develop FI (Kaiser, 2012), (Gabet \& Müller, 2017).

Ancient Rome (Dragomanov, 1869). The 1st century $\mathrm{BC}$, the presentation format is painted clay dolls $25 \mathrm{~cm}$ high. Until the XVII century, fashion was used to denote class distinctions. Fashion presentation doesn't stand out in a specific 
format. In the XVII century Louis XIV, issued a special decree on changing clothes for the season, which became a part of the new court etiquette. This helped to the birth of FI in France (Kaiser, 2012). Twice a year, two wax dolls dressed in the latest fashion (from 1642) were sent from Paris to the capitals of other states. They used fashion as a presentation format until the 1860's, after which they were replaced with mannequins (Waddell, 2004). At that time, fashion magazines were already distributed in Europe. In the XVIII century, the fashion-maker was the fashion designer Marie-Antoinette Rosa Bertin. England was the center of the technical revolution of the 60 's XVIII century. A spinning machine, a mullet machine, a mechanical and automatic weaving machine, a steam engine machinery appeared. Manufactory, based on manual labour, was replaced by a machine production. The needs of the emerging bourgeois society in fashion embodied the ideas of social equality after the Great French Revolution (1789-1794) (Waddell, 2004). In the surrounding of the gentry, new forms of clothing appeared, which later became classical: dress coat and redingote. They are designed for a person heaving an active lifestyle. These clothes were no clear signs of social status. At the same time, dandies appeared in England. They introduced into the fashion white shirts, ties and vests. Until now, the combination of brown, black, gray and white, are considered classics in men's clothing. For the first time, a noble and wealthy man became an object of imitation. Since that time, women's fashion began to change more often than the men's one. In the bourgeois society of the XIX century, a woman was a kind of "showcase" of the success of her husband (Hollander, 1982). Fashion changed very often in the interests of the development of FI, one style followed another: the Empire style of Napoleon I gave way to the romanticism of the Restoration era. He was replaced by Biedermeier and historicism, the "second Rococo" of Napoleon III era and eclecticism - the century ended with the formation of a modernist style. In France, the emergence of jacquard fabrics, a multi-color printing press, a circular-rotary machine for the production of tulle and lace, improved spinning and weaving machines, the use of artificial colors made it possible to develop ready-made clothing. The development of FI in the XIX century led to the emergence of High Fashion. Creator Charles Frederick Worth, invented the profession of a mannequin (Hollander, 1982). Worth hired "doubles" (female models), created seasonal collections; fashion got a seasonal rhythm. He founded of the fashion management system.
Regular updating of styles and silhouettes was a powerful factor in the expansion of sales and corresponded to the needs of a market economy. Having made a short break in the XVIII century, from the XIX century the upper classes, again began to emphasize their class difference with the help of fashion. In 1868, Worth created the Chambre Syndicate De La Haute Couture, which still exists today. Since this point couturiers can only be called members of this organization. In order to join the Syndicate, it was necessary to meet the initial requirements - to make models for individual orders using manual work. Currently, the couturier can call himself one who is a member of Fédération de la Haute Couture et de la Mode (FHCM). New forms of trade contributed to the development of mass fashion. In the 1850's department stores appeared in which they demonstrated new models of clothing. In the 1860's jackets and coats, originally menswear, became fashionable. In the era of the Third Republic (1870-1940) in France, fashion legislators considered fashionable tailors. The leaders of fashion were also representatives of Bohemia - famous actresses. Fashion magazines contributed to the spread of fashion. The beginning of the XX century is the flourishing of culture and art. At this time, Art Nouveau artists put forward the idea of costume individualization, which was realized in mass fashion only 70 years later. By 1910, ready-made clothes were already on display in stores. The emancipation movement borrowed trousers and practical materials from a men's suit. On June 24, 1911, Paul Poiret arranged the first masquerade "1002 Nights, or the Persian Celebration". In 1912 he organized the "Bacchus Celebration" and Isadora Duncan entertained the guests with dances. Costumed balls were in fashion before the World War I. In 1913, in Deauville, Gabrielle Chanel opened her first salon, offering clients comfortable clothing from knitwear (Gabet $\&$ Müller, 2017). The basis for the formation of a functional suit became a sports suit. From 1983 to 2019, the Chanel fashion house was headed by Karl Lagerfeld. It was replaced by Virginia Wiard. In 1914, in London, Madame Paken organized the first fashion show with musical accompaniment. For the first time, an underwear show for women was held in New York in 1915. In the 1920's, there was a need to build podiums, through which a large number of customers could get acquainted with the presented outfits. Neiman Marcus - the universal store, since 1926, arranged a weekly fashion show. Boutiques competed among themselves in the beauty of the dresses and their presentations. Since the 1930's, thanks to cinema, 
Hollywood actresses have become fashion-makers (Kaiser, 2012). In 1943, Europe was in conditions of World War II. Eleanor Lambert organized the First Week of Fashion in New York - Press Week. This brought the American fashion to a completely different level. After the World War II, Christian Dior presents a collection of 1947 New Look. He introduces the fashion for the season, and this innovation was fixed by FHCM. Now all fashion houses are members of FHCM and obliged to submit two collections a year in strictly defined terms. In 1952 Florence fashion house Brioni organized the first show of men's clothing (Gabet \& Müller, 2017). Since the 1950's, the circulation of mass clothing has increased significantly in Europe and the United States. Fashion markets become global. Nylon, capron and elastane have changed the idea of linen. 1960-1970's mass consumption introduced for the economic ineffectiveness of the Haute Couture concept. The fashion show of the first half of the XX century was carried out in silence that was interrupted by the voice of the girl who proclaimed the numbers and names of the sets. In the 1964 show, Andre Curère's models went out to loud musical bits. After 1967, all fashion shows have gone through music. They have become a full-fledged entertainment show. Since the 1990's, companies have become involved in organizing fashionable shows: Bureau Betak, M/M Paris, OBO LLC, YO Events Designers, Villa Eugenie, Sun Design Group, La Modeen Image, Eyesight, etc. This is the time of supermodels. During the XX century the classic traditional podium, was transformed into a flat podium; high podium; long podium; П-shaped podium; square podium; flat П-shaped podium; flat roads podium converge letter V; podium scene, micro podium; round arena with a pavilion in the center; wide space for defile between opposite visual rows; sleek black back and black floor podium; the podium has changed various colors, different cover of the podium was used; podium in the form of a large table, etc. (Waddell, 2004). Fashion shows presented on non-standard locations: desert, the Great Wall of China, circus, railway station, opera, hotel, airport, restaurant, cafe, garbage dump, playground, etc. In addition to professional models was took part in the shows as a models of children, models of age, plus size, people with disabilities, bodybuilders, dancers, clients of the brand, etc.

In 1996 the Internet appeared - information became the basis of the modern information world, changing it forever. Fashion shows began to be accompanied by online broadcast in the 2000's (Čiarnienè \& Vienažindienè, 2014). New opportunities that have emerged due to the expansion of computer applications have largely begun to determine the nature of communication, the style of communication, ways of transfer, exchange and saving of information of human society. They began to change the appearance and pace of development of the culture, science, education, business, politics, fashion, etc. The rapid development of innovations are changed the capabilities and needs of the human-consumer. Accordingly, the requirements, the functional meaning and the meaning of the subject of the material culture closest to a person - costume and clothing - have changed (Huang \& Chang, 2018). The cornerstone of culture has become the fastgrowing human needs for self-expression through the formation of his individuality. FI locally is received a historic chance of independence with new opportunities. INF has appeared since the advent of the Internet since 1996. The independence of time have enabled FI to influence money, principles, laws, creating costumes and clothing, their functions, presentation, acquisition, use, disposal and reuse today.

In the XXI century there is no one definite fashionable trend. Today everything is fashionable. Creative energy is aimed at creating new combinations of "old" things. The direction of Sustainable Fashion appeared. Street fashion or street style is influencing the world of High Fashion. Entering the worldwide audience 24/7 has given FI the independence in the matter of creating, and most importantly, variations, a new commercial rhythm. In recent years, e-commerce has made the fashion market independent. Trading through online stores is done around the world 24/7. Some brands are developing the idea of "See now, Buy now". One of the main promotion channels is the format of vlogs, blogs, social networks (Huang \& Chang, 2018). Special guests at the fashion event are bloggers. They take photo shoots, which subsequently appear in glossy magazines and social networks. The line between men and women clothing is erasing. There are mixed shows. Male models demonstrate women clothing, and women demonstrate male one. The final output of the models is called Instagram moment. Fashionable clothes are presented not only by people but also by robots, drones, etc. Today brands are independently experimenting with alternative presentation formats: independent shows, fashion parties, exhibitions and media brunches. The presentation format often makes the costume creation process open, introduces new technologies to tailors, provides an opportunity to visit a photo studio and witness the shooting of a new look book collection. The presentation 
has the format of an art project on the verge of art and current fashion. The presentation of the collection is often held in the new showroom of the brand, which officially opens on the day of the event combining the presentation of a collection of clothes and the release of a music album, etc. The COVID-19 coronavirus pandemic has greatly accelerated the digitalization of the world. Some Fashion Weeks, Fashion Summits, events, fashion presentation formats have completely switched to online. The market of Digital Fashion, Digital Couture, NFT is actively developing as an alternative to fast fashion. Artificial Intelligence (AI), Virtual Reality (VR), the Internet of Things (IoT) are influenced new requirements of the growing value and the rapid development.

This gives a historic chance of independence in the matter of presenting themselves and their work $24 / 7$ to both already well-known and young designers and new brands. The modern new clothes creation technologies are: 3D (Cvetković, 2018), $4 \mathrm{D}$ printing, NNI, smart clothes: the wearable computing and smart clothing for healthcare (Lynn et al., 2018), (Lihong \& Xiaodong, 2012), (Kemppainen \& Rönkä, 2015), (Kumar et al., 2015), (Astaras et al., 2017), BF, etc. It becomes popular on the market.

The development of new clothing technologies has led FI to independence. The technology of creating clothes in the nearest future will become a personal gadget and will appear at every home, like a mobile phone or tablet. In the nearest future, using the gadget, anyone can create for themselves the necessary clothes anywhere and anytime 24/7. Gadgets make these clothes trendy and fashionable. Thanks to environmentally friendly new materials, unnecessary clothes can be utilized or recycled without polluting the environment. The analyzed types of clothes and new technologies give the possibility to actively develop new presentation formats.

The methodology. In the process of the research, special and definite scientific methods were used: cultural, historical and comparative, comprehensive, informational. The methodological basis of this study was the cultural method. The specifics of this research made it necessary to use the historical and comparative method of the fashion presentation formats. The social conditions of the era, the needs of society in conjunction with the fashion presentation formats were used as the mains components of the complex research method. The Internet is an integral part of the application of the information method, which is a means of obtaining, disseminating and exchanging research information between modern, rationally thinking people in information concepts.
The results. Analyzing the appearance, development and transformation of fashionable clothes presentation formats, footwear, accessories, jewelry that have emerged as the result of the progress, the purpose of this study is to introduce a new term into modern FI - INF. There are no scientific papers on this theme at the moment. So this theme requires serious further research.

Discussion. INF has not been researched yet. The sources of the research paper included the scientific and popular articles and the latest practical, experimental and laboratory research material. The methodological research was formed under the influence of the studies by A. Toinbi, V. Hlushkov, M. Kahan, U. Jones, G. Hegel.

Conclusion. As a result of this study, the sources of the research paper included the scientific and popular articles and the latest practical, experimental and laboratory research material have been analyzed. The research field of cultural studies is expanded. The processes of cultural activity which create material values in the form of clothes, footwear, accessories, jewelry have been studied. The development of culture is investigated by identifying the features of creativity of prominent figures, who create world cultural masterpieces and develop new cultural styles. The change of the fashionable clothes presentation formats and their role in the formation of human being and society development is found out.

The appearance of the new types of clothes is considered. It has been identified that the usual spectrum of clothes functioning, denoting social class affiliation, as well as continuing to perform utilitarian and aesthetic functions, is substantially complemented. New technologies of creating clothing provide a significant expansion of the range of its using. It has been found out that the developments of the newest clothes functioning reflect the epoch, time and human needs of the Third Millennium. Thanks to 3D and 4D printing, NNI, smart clothes: the wearable computing, smart clothes for healthcare, BF, etc., the modern ways to new aesthetic lines for FI, as well as to new performances and presentations for clothing are appeared. This potential has posed a number of advantages compared to traditional manufacturing processes. It is fast design process, timeliness and costs reducing dealing with inventory, warehousing, packaging, and transportation. New technologies, as well as new features of clothes allow to review the seasonal cycles of creating clothes, the calendar of their delivery and develop new formats for the presentation of new clothes.

The position, role and specifics of the fashionable clothes presentation formats are identified. The 
fashionable clothes presentation format including technical progress and the specifics of each historical period has changed several times. The analysis has shown that the fashionable clothes presentation formats changed in history because of the appearing of new clothes, new human needs and the development of production technologies. The fashionable clothes presentation format is influenced by changes and extensions of the functional values of clothes associated with the human needs which change in the process of human development. Has been, in fact, a confirmation of the transition of humanity to an independent stage in the development of society and civilization. That is why the area of development of the new fashionable clothes presentation formats is relevant and necessary today.

In relation to everything that was said above, the results of the study suggest that INF takes positions of creativity, novelty and freshness. This study influenced the development of the modern cultural processes. It confirmed the necessity of the further research of the fashionable clothes presentation formats.

\section{References}

Astaras, A., Lewy, H., James, C., Katasonov, A., Ruschin, D., \& Bamidis, P. D. (2017, January 1). Unobtrusive smart environments for independent living and the role of mixed methods in elderly healthcare delivery: The USEFIL approach. Health Care Delivery and Clinical Science: Concepts, Methodologies, Tools, and Applications. IGI Global. 1307-1324. doi.org/10.4018/978-1-5225-3926-1. ch066 [In English].

Cannon, G. (2006). The life and mind of oriental Jones: Sir William Jones, the father of modern linguistics. Department of English, Texas A\&M University. [In English].

Čiarnienè, R. \& Vienažindienè, M. (2014). Management of contemporary fashion industry: characteristics and challenges. Procedia - Social and Behavioral Sciences, 156, 63-68. doi:org/10.1016/j. sbspro.2014.11.120 [In English].

Crump, S. S. (1992). United States Patent No. 5,121,329. https://patents.google.com/patent/US5121329A/ en\#patentCitations [In English].

Cvetković, D. (2018). 3D printing. London: Intech Open. https://www.intechopen.com/books/3dprinting doi:org/10.3390/su9071266 [In English].

Dragomanov, M. (1869). The question of the historical significance of the Roman Empire and Tacitus. http:// chtyvo.org.ua/authors/Drahomanov_Mykhailo/ Vopros_ob_ystorycheskom_znachenyy_Rymskoi_ ymperyy_y_Tatsyt/ [In English].

Gabet, O., \& Müller, F. (2017). Christian Dior: Designer of dreams. Thames \& Hudson. https://www. thamesandhudsonusa.com/books/dior-designer-ofdreams-hardcover [In English].
Glushkov, V. (1969). Modern problems of scientific management. [In English].

Glushkov, V. (1973). Some problems of using computer machines for managing social processes. At an international conference. [In English].

Glushkov, V. (1986). Some problems of automata theory and artificial intelligence. Cybernetic, 477, 424441. [In English].

Hollander, A. (1982). When the Worth was king. [In English].

Huang H. S. \&, Chang, C. T. (2018). A case study of the fashion show curatorial and experience marketing. The perspective of the actor network theory. KEER2018, Go Green with Emotion. 7th International Conference on Kansei Engineering \& Emotion Research, 530, 478-488. [In English].

Kagan, M. (2007). Selected works in 7 volumes. (Vol. 3). Petropolis, 758, 654-739. [In Russian].

Kaiser, S. (2012). Fashion and cultural studies. (1st ed.). Berg Publishers. [In English].

Kemppainen, A., \& Rönkä, K. (2015). Roll-to-roll printed and flexible electronics for wearable, healthcare and IoT. In 2015 ICFPE: Program Book, 6th International Conference on Flexible and Printed Electronics, ICFPE 2015 - Taipei, Taiwan, Province of China. [In English].

Kumar, A., Levin, E., Cowings, P., \& Toscano, W. B. (2015). Evaluation of the accuracy of Astroskin as a behavioral health self-monitoring system for spaceflight. NASA Technical Report Server. Document ID: 20150021842 [In English].

Lihong, B., \& Xiaodong, L. (2012). Towards textile energy storage from cotton t-shirts. Advanced materials. 24(24). 3246-3252. [In English]. doi. org/10.1002/adma.201200246

Lynn S. K., Watkins C. M., Wong M. A., Balfany, K., \& Feeney D. F. (2018). Validity and reliability of surface electromyography measurements from a wearable athlete performance system. Journal of Sports Science and Medicine 17, 205-215. [In English].

Toynbee, A. (1946). A study of history. Oxford University Press. [In English].

Waddell, G. (2004). How fashion works: Couture, ready-to-wear and mass production. UK Ames, Iowa Blackwell Science. https:// trove.nla.gov.au/work/10223842?q\&version Id $=11892458+220734203+254518775$ [In English].

Yang, S., Song, Y., \& Tong, S. (2017). Sustainable retailing in the fashion Industry: A systematic literature review. Sustainability, 9(7), 1266. MDPI AG. [In English].

Надійшла до редколегії 21.06.2021 